\title{
Eldorado radiates Hope
}

David Spurgeon reports from Ottawa on the Port Hope affair

As A result of continuing public concern about radioactive contamination in the Port Hope area of Ontario, a federal-provincial task force drawn from different departments of the national and Ontario governments was formed late last month to supervise a clean-up of the area. The force will also help the Atomic Energy Control Board (AECB) to discuss the significance of radioactivity in other locations in Canada.

The formation of the task force was announced by the Federal Minister of Energy, Mines and Resources, Alastair Gillespie, after documents were tabled in the House of Commons reporting on the Port Hope situation. These revealed a total of 109 locations in 25 areas of Canada where radioactivity is known or suspected.

Radioactivity from radon gas was discovered last year in a Port Hope school and at several other sites, including private homes. It came from waste disposal from Eldorado Nuclear Limited, which had recovered radium in the 1930s and 1940 s from pitchblende-radium-silver ores mined in the Northwest Territories. The abundant pitchblende (uranium) content was largely discarded at that time because it was thought to be of little value. The radium extracted was used for cancer treatment and in luminous dial painting.

During that period, wastes were disposed of at Port Hope in piles on and close to the Eldorado plant. Toxicity and radiation hazards standards were not then well established. Some of the waste is believed later to have found its way to various parts of the town in the form of fill that was trucked about.

Wastes were also sold to a company in the United States for recovery of metals, which involved shipping the wastes about, and some of the contamination apparently came from spills en route, or from storage. A building programme by Eldorado Nuclear Limited may also have resulted in contamination of rubble, fill and reclaimed building materials.

During the Christmas festive period last year, a street-by-street survey of the whole town of Port Hope was made by the AECB and the Ontario health ministry. Samples of air were collected for analysis when abnormal radioactivity levels were found.

At one private home, air samples taken outside the house showed radon concentrations ranging from 200 to 400 times the acceptable level for continuous exposure. Contaminated fill had been used to fill a ravine behind the house. The health ministry has closed a school, and several families have vacated their homes.

A number of recommendations have already been carried out to remedy the situation in Port Hope. The task force's immediate priority is to complete the investigation and clean-up in Port Hope. The AECB has opened a public information centre there and has assigned two staff officers and two vehicles to the investigation, and plans have been made to carry out an aerial radiometric survey.

If nothing else it seems likely that any future plans to install nuclear capacity on the shores of lake Ontario will be subjected to close scrutiny in the wake of the Port Hope affair. All the same, it remains a source of worry that minor warnings about Port Hope had been given over many years before the latest developments occurred.

\section{Generating nuclear heat}

The use of nuclear energy, as Wendy Barnaby indicates in this report from Stockholm, is a sensitive issue in Sweden

Mr Ralph Nader, the American consumer expert, has said that the Swedes' nuclear energy programme is hindering their ability to work for world peace. At a meeting of environmentalists in Gothenburg, Mr Nader said he was disappointed with the Swedish Prime Minister, Mr Olof Palme, who had in his opinion been too quick to accept arguments for a rapid expansion of nuclear power. (Mr Palme's Social Democratic government plans to have 13 reactors in operation by 1985). If Sweden concentrated on nuclear energy it could not refuse to back other countries making the same choice. But, $\mathrm{Mr}$ Nader maintained, the only way to stop the proliferation of nuclear weapons is to stop the spread of nuclear energy for peaceful purposes as well.

Meanwhile, $\mathrm{Mr}$ Björn Gillbergoften called "Sweden's Nader"-is waiting for a court decision in one of his many battles against nuclear power. The case, fought on behalf of a local environment group by Gillberg and a lawyer, Gunnar Michelson, against the State Power Board, concerns permission to operate reactors three and four at the Ringhals plant on the west coast. Technicalities have put the case into the court of appeals of the Water Court, whose jurisdiction is limited to considering whether the reactors could damage their water environment. The only aspect of the plant able to be discussed has therefore been the release of cooling water into the sea.

If permission is given for the reactor to be operated, 175 cubic metres of cooling water per secondthe largest release in the world-will flood into the sea through pipes so large that trucks can be driven through them. The environmentalists contend that the effect of a court decision in favour of operation would be to cause a certain number of deaths from the water's radioactivity, and that the court has no right to make decisions which kill people. The State Power Board agrees that every year of opera- tion would cause some cancers and genetic defects, although its estimation of their number is smaller by a factor of eight than the environmentalists'.

As the reactors are already being built, it is highly unlikely that permission to operate them in some form or another will be refused. Mr Gillberg is of course aware of this, but maintains that nuclear power should be fought on all fronts, no matter how small the odds of winning may be.

Not that Mr Gillberg and his friends should be unhappy with the latest opinion poll on nuclear energy. Fully $54 \%$ of the sample wanted no more than the five reactors already builtand this position was taken by $41 \%$ of Social Democratic supporters. Only $34 \%$ of the sample wanted more than the present five: the rest did not know. More surprising, however, was that $75 \%$ of the sample preferred to curb their standard of living in order to avoid an increase in energy use, rather than to raise their standard of living and accept the consequences of using more energy. And the majority comprised $70 \%$ of the Social Democratic respondents. The vital question, though, is not the divisions in opinion polls, but the effects they have, in this election year, on public policy. 